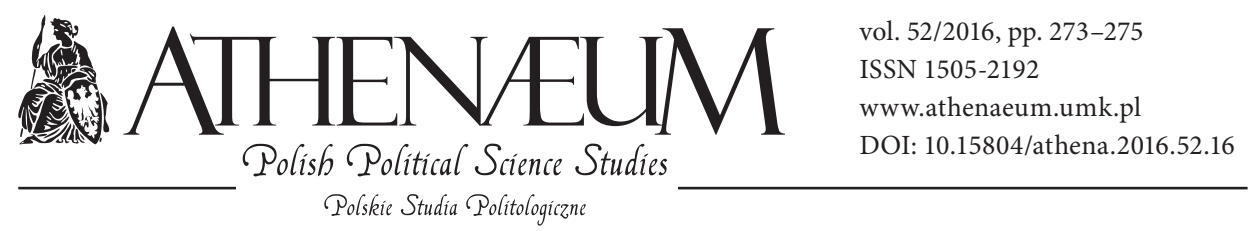

\title{
Carl Schmitt, Legalność i prawomocność, translation into Polish Bogdan Baran, ALETHEIA, Warszawa 2015, pp. 215
}

\section{Judyta Bielanowska*}

Carl Schmitt (1888-1985) is one of the most significant, yet on account of his NSDAP membership, one of the most controversial science luminaries in the matters of the state and international law; a social philosopher and theoretician of law. His political writings on the legitimacy of power, parliamentary tradition, sovereignty and authority of the institution are regarded as the canon of contemporary conservative thought. His most well-known works that have been translated into Polish include: Political Theology and Other Works (2000), The Leviathan in the State Theory of Thomas Hobbes (2008), Constitutional Theory (2012), Legality and Legitimacy (2015).

The latter of Schmitt's books mentioned, Legality and Legitimacy, completed on July 10th, 1932, contains two major chapters (The System of Legality of the Parliamentary Legislative State and Three Extra-

* Nicolaus Copernicus University, Faculty of Political Sciences and International Studies. ordinary Lawgivers of the Weimar Constitution) divided into subchapters, preceded by the author's preface and concluded with the summary of the considerations from the main content. Moreover, the 2015 publication includes an editor's note, a list of corrections made either by Carl Schmitt in the respective editions, or the editors, as well as the facsimile of the author's copy and the text of the Constitution of the German Reich of August 11th, 1919.

At the very beginning of his considerations, short after the preface, Schmitt reveals the main points of his analysis, which he successively develops in further sections. The distinction between 'legality' and 'legitimacy' becomes the centrepiece of his reasoning, and his further reflections focus on the polarity of these concepts. Gradually, the author draws the reader into the complex nature of legal science, points to multiple possible interpretations of the term 'law' on the ground of understanding the state as a 'political community', with the 
law determining the type of this community. According to Schmitt, the law, which is both omnipotent and understood as a set of abstract, general, not specific norms, provides fertile ground for totalitarian systems, and therefore may become a double-edged sword, as on the one hand, it becomes a tool for oppressing the society which has no constitutional guarantees of inviolability of its rights and freedoms, nor a possibility to resist the tyranny which seeks legitimacy of its actions in the relativity of the law; on the other hand, a normative system in the legislative state, which Schmitt puts on equal terms with the parliamentary republic, remains in the condition of permanent threat from the existing competitive law-making entities, such as the nation giving vent to its most pressing needs and emotions through the participation in a referendum, or President's decrees, which have the force of law on the grounds of an incompetently constructed constitution.

The overall picture that emerges from Schmitt's analysis is explicitly pessimistic and painfully true. Demonstrating his unquestionable knowledge of the science of law, the author proves that the legality of parliamentarianism is a fallacy which has nothing in common with the 'rule of law'. The relativity of each and every aspect of individual and collective existence, which is an inherent feature of a democratic legal state, and the lack of permanent axiological systems contribute to the fact that the law expressed in a given legislation, such as the basic law, remains a dangerous tool of manipulation which every parliamentary majority may take advantage of for its current needs with regard to elections and power. The law which is applied in a consistently democratic manner lifts the responsibility for all actions taken in a relatively short term of parliamentary office. According to Schmitt, it is not only a manifestation of a basic pathology of the democratic system, but also an indelible contradiction, paradox of the most basic functions of the law, as for these shortcomings to be removed one would have to resign from democracy, which is cherished by the privileged but depersonalised majority.

Carl Schmitt's main message conveyed by the Legality and Legitimacy consists in indicating the danger arising from a dogmatic perception of legalism constituted by the majority. For it is in the name of legality that the majority, which constitutes the main pillar of the parliamentary system, may cancel the minority's right to any resistance. Therefore the law is not even a democratic fiction. It does not exist at all. The applicable law is nothing more than a dictatorship of a currently governing party, as there is no permanent connection of legal standards with the unalterable, permanent axiological content. In addition, in this context, Schmitt proves that what is identified uncritically in the widespread awareness, namely law and justice, have very little in common and most of the time they are mutually exclusive, as in the parliamentary system, the law, which is inherently dependent of the current political 
decision-maker, may not guarantee justice, which is a permanently universal value.

The reader will not find a light narrative and a loose style in the book. Quite the contrary, Legality and Legitimacy is a profound, scientific analysis, written by an unquestionable authority in the field of the science of law. From the very beginning, by adopting a strictly legal language, Schmitt exposes the most essential, and at the same time the most dangerous pathology of democracy, namely the inefficiency of the legal system which consists in the complete freedom to interpret legal regulations, separation of legal standards of substantive law and their practical implementation, as well as changeability, which also regards the basic law, depending on the majority understood in arithmetic terms. On the one hand, the legal style of the work is conducive to a scientific, impartial sine ira et studio analysis, but on the other hand, it hinders any discussion with the author's key ideas, especially if the readers have not enough competence in jurisprudence.

However, regardless of the nature of Carl Schmitt's text, the main advantage of the work under scrutiny is its timeless appe- al. It must by noted that the text was completed in 1932, so it was being written in certain well-defined circumstances, and its main purpose was the criticism of the Weimar constitution of 1919, whereas the secondary goal, voiced quite expressly, was the disparagement of parliamentary democracy. Schmitt achieved something truly spectacular. He anticipated what was to happen in the 21st century when the opinions for the need of changing the Constitution (nota bene, the only legal act which should remain unalterable), or even writing it anew, are voiced across the entire political scene in a manner which is so explicit that the average citizen has lost the ability to discern where democracy ends and where totalitarianism starts, what is a value sensu proprio, and what is a tool for achieving a morally questionable goal. It is thus hard to disagree with Schmitt when he concludes his work with a bitter afterthought: "the fiction of neutral functionalism in the face of the truth shall soon draw to a close. Then the truth shall take revenge. It shall take revenge - but it shall not be victorious" (p. 153). It is fair to add: as much then as now. 